\title{
Repeated short-term organic amendments effects on physical and biological properties of a San Antón soil ${ }^{1,2}$
}

\author{
Ian C. Pagán-Roig', Joaquín A. Chong ${ }^{4}$, José A. Dumas ${ }^{5}$ and \\ Consuelo Estévez de Jensen ${ }^{6}$
}

J. Agric. Univ. P.R. 100(2):123-140 (2016)

\begin{abstract}
The objective of this work was to measure the effects of repeated shortterm organic amendments that we termed soil treatment management cycles (STMC) on physical and biological properties of a San Antón series soil. Each STMC lasted 60 days and consisted of incorporating $5 \%$ organic matter from coffee pulp compost; the planting, growth and incorporation of an intercrop of four green manure species; and the application of mycorrhizae and compost tea. The treatments were labeled: CLO, CL1, CL2 and CL3; where CL0 was the control, CL1 received one STMC, CL2 and CL3 received two and three STMC, respectively. The STMC intended to mimic the overall effect of a sustainable agricultural system, not to measure the individual effects of the practices. All treatments (CL1, CL2, CL3) showed an increase in soil organic matter ( $p \leq 0.05)$. When compared to the CLO control, saturated hydraulic conductivity increased and bulk density decreased in all soils. Soil macroporosity was significantly increased by CL2 and CL3. Soil aggregate stability increased in CL1, CL2 and CL3 plots. Microbial biomass $C$ increased in treatment CL3, and microbial biomass $\mathrm{N}$ increased in CL2 and CL3. The production of stable aggregates was correlated to humic acid content and positively influenced all other physical parameters assessed in this study. The STMC had a positive impact on soil properties by increasing the soil organic matter as well as the humic acid fraction. Soil macroporosity, defined as porosity with radius $>38 \mu \mathrm{m}$, was significantly increased by treatments CL2 and CL3. All of the organic matter fractions, including total organic matter, humic acid content, microbial biomass $\mathrm{C}$ and microbial biomass $\mathrm{N}$ were significantly increased by one or more STMC.
\end{abstract}

Key words: Mollisol, organic matter, mycorrhizae culture, green manure, compost tea, coffee pulp

${ }^{1}$ Manuscript submitted to Editorial Board 22 December 2015.

${ }^{2}$ This work was supported in part by the NRCS-Conservation Innovation Grants, by the USDA National Institute of Food and Agriculture (Hatch project) and the Agricultural Experiment Station of the University of Puerto Rico.

${ }^{3}$ Ex-Graduate Student, Department of Agroenvironmental Sciences, University of Puerto Rico-Mayagüez Campus. Josco Bravo Agroecological Farm, Toa Alta, PR 00954.

${ }^{4}$ Plant Physiologist and Associate Professor, Department of Agroenvironmental Sciences, University of Puerto Rico, Mayagüez Campus. E-mail: joaquin.chong@upr.edu.

${ }^{5}$ Chemist and Professor, Department of Agroenvironmental Sciences.

${ }^{6}$ Phytopathologist and Professor, Department of Agroenvironmental Sciences. 


\title{
RESUMEN
}

\author{
Enmiendas orgánicas y sus efectos en las propiedades físicas y biológicas \\ de un suelo San Antón
}

\begin{abstract}
Se utilizaron varias prácticas de enmiendas orgánicas en un suelo de la serie San Antón (Mollisol) y se cuantificaron los cambios respectivos en la capacidad física y biológica de este suelo. Al conjunto de estas prácticas le dimos el nombre de manejo de ciclos de tratamiento de suelo (en inglés, soil treatment management cycles o STMC). Cada STMC duró 60 días y consistía en incorporar $5 \%$ de materia orgánica proveniente de composta de pulpa de café, la plantación, crecimiento e incorporación de cuatro especies como abono verde y la aplicación de micorrizas, además de té de composta. Los tratamientos fueron: CL0, CL1, CL2 y CL3; donde CLO fue el control, CL1 tuvo un STMC, CL2 y CL3 tuvieron dos- y tres-STMC, respectivamente. Los STMC se efectuaron con el propósito de asimilar el efecto conjunto de un sistema agrícola sustentable y no con el propósito de medir los efectos individuales de cada práctica. Todos los tratamientos (CL1, CL2 y CL3) resultaron en un aumento en la materia orgánica del suelo ( $p \leq 0.05)$. La conductividad hidráulica saturada aumentó y la densidad del suelo se redujo al compararlo con el CLO control. La macroporosidad del suelo aumentó significativamente en CL2 y CL3. La estabilidad de agregados del suelo aumentó en CL1, CL2 y CL3. La biomasa microbiana C aumentó en CL3 y la biomasa microbiana Naumentó por CL2 y CL3. La producción de agregados estables del suelo se correlacionó con el contenido de ácidos húmicos y tuvo efectos positivos en todos los demás parámetros físicos observados en este estudio. Los STMC impactaron las propiedades del suelo cambiando la cantidad de materia orgánica, así como la cantidad de ácidos húmicos. La macroporosidad del suelo, definida como la porosidad de radio $>38$ $\mu \mathrm{m}$, incrementó significativamente para los tratamientos CL2 y CL3. Todas las fracciones de materia orgánica, incluyendo la materia orgánica total, contenido de ácidos húmicos, biomasa microbiana $\mathrm{C}$ y biomasa microbiana $\mathrm{N}$ fueron significativamente superiores con uno o más STMC.
\end{abstract}

Palabras clave: Mollisol, materia orgánica, micorriza, abono verde, té de composta, pulpa de café

\section{INTRODUCTION}

Soil degradation seriously threatens world food security (Pimentel et al., 1995; Bumb and Baanate, 1996; Pinstrup-Anderson and Pandya-Lorch, 1998; FAO, 1999; Lal, 2000; Henao and Baanante, 2006). Inadequate soil management has been pointed out as one of the main causes of worldwide soil degradation (Henao and Baanante, 2006; Lal, 2007). Deficient management of soil physical properties has led to the deterioration of soil fertility, reduction of productivity and has had a negative environmental impact (Lal, 2000). Soil organic matter (OM) has been described as the most important indicator of soil quality because of its positive impact on physical, chemical and biological soil properties (Reeves, 1997; Carter et al., 1999; Lal, 2004). It has been extensively reported that physical properties, most notably structure, are largely governed by soil OM content and quality (Khaleel et al., 1981). 
The management of soil physical properties becomes of major concern in the tropics since it has been commonly established that OM decomposes at a faster rate compared to temperate climates (FAO, 1999).

Management of organic carbon has been suggested as a primary practice to enhance and maintain soil structure in short- and longterm agricultural operations (Reeves, 1997). In sustainable agriculture systems, practices such as compost additions, enhanced fallows, the use of compost tea and other organic and biological amendments are being adopted with the purpose of improving soil structure and nutrient status. The incorporation of organic amendments such as animal manures (Annabi et al., 2011), vermicompost (Ferreras et al., 2006), cover crops and other agricultural by-products (Tejada et al., 2007; Tejada et al., 2008b) have been demonstrated to enhance a wide range of physical properties directly linked to crop productivity. Composted municipal solid waste and sewage sludge can also enhance soil structure; however, using these materials is potentially hazardous, loading the soil with heavy metals (Aggelides and Londra, 2000).

The use of cover crops in particular has been shown to enhance soil physical characteristics (Fischler et al., 1999; Tejada et al., $2008 \mathrm{~b}$; Torres, 2009). Torres (2009) found greater aggregate stability, enhanced hydraulic conductivity, greater water retention and lower soil bulk density (Bd) after two years of an Arachis spp. cover crop establishment in a San Antón soil series (fine-loamy, mixed, superactive, isohyperthermic Cumulic Haplustolls). Fischler et al. (1999) reported increased water infiltration and reduced $\mathrm{Bd}$ after incorporation of Crotalaria sp. residues. In an experiment evaluating alternatives for restoring degraded soils, Tejada et al. (2008b) found that the incorporation of Trifolium pratense L. increased structural stability and reduced $\mathrm{Bd}$.

Soil microbial activity has been reported as another important index of soil quality, closely related to the cycling of soil nutrients (Oberson et al., 2006; Zhao et al., 2009), pathogen suppression and pest control (Drinkwater et al., 1995; Altieri and Nicholls, 2003). Soil microbial activity is also related to soil physical properties principally by the action of microbial products on stabilization of aggregates (Six et al., 2004). Mycorrhizae microorganisms are the primary soil biological functional group associated with the improvement of soil physical properties, nutrient uptake and biological quality adding considerable sustainability elements to crop production (Cardoso and Kuyper, 2006). However, microbial activity (including the mycorrhizae) is very sensitive to agricultural management, specifically, regarding the level of organic carbon entering the agro-ecosystem (Angelides and Londra, 2000; Gunapala and Scow, 1998; Tejada et al., 2007). 
The objective of this study was to evaluate the effect of repeated soil treatment management cycles (STMC) of coffee pulp compost applications, green manure growth and the addition of compost tea and mycorrhizae on the physical and biological properties of a Mollisol soil in the semi-arid southern coastal region of Puerto Rico.

\section{MATERIALS AND METHODS}

\section{Experimental design and treatments}

The experiment was conducted at the University of Puerto Rico Agricultural Experiment Station in Juana Díaz, Puerto Rico $\left(18^{\circ} 01^{\prime} 45.65^{\prime} \mathrm{N}, 66^{\circ} 31^{\prime} 34.17^{\prime \prime} \mathrm{W}\right)$. The soil at this location is a San Antón soil series (fine-loamy, mixed, superactive, isohyperthermic Cumulic Haplustolls). The experimental plot had a fallow history of more than three years. The field experiment consisted of four treatments arranged in a complete randomized block design with four replications per treatment, for a total of 16 experimental units. Each experimental unit was a $2.4 \times 3.0 \mathrm{~m}$ plot. The plots were drip irrigated twice a week with well water as needed. The experimental plot was mechanically cleared of vegetation and divided based on the randomized experimental setup described above with four treatments; all weeds around the plots were mechanically controlled with a tractor mower as needed.

Each STMC lasted 60 days and included the following three practices: 1) incorporation of 5\% OM from coffee pulp compost; 2) planting, growth and incorporation of a cover crop mixture of four legume species Crotalaria juncea (sunn hemp), Canavalia ensiformis (jack bean), Vigna unguiculata (cowpea) and Mucuna pruriens (velvet bean); and 3 ) the addition of mycorrhizae (MycoApply ${ }^{\circledR}$ Soluble Endo) ${ }^{7}$ and compost tea. The control CLO did not receive any STMC. Each STMC was either not performed (CL0), or performed one time (CL1), or twice consecutively (CL2) or three times consecutively (CL3). The STMC were scheduled starting with CL3, followed by another cycle with CL2 and CL3 applied at the same time, and the final STMC with CL1, CL2 and CL3 at the same time. The CL0 treatment never received any STMC, but the soil was tilled when the other treatments were tilled. After all treatments were established, eggplants were grown and the yield quantified in each of the experimental plots.

\footnotetext{
${ }^{7}$ Company or trade names in this publication are used only to provide specific information. Mention of a company or trade name does not constitute an endorsement by the Agricultural Experiment Station of the University of Puerto Rico, nor is this mention a statement of preference over other equipment or materials.
} 
The purpose of the treatments was to mimic the overall effect on the soil of a sustainable agricultural system and not to measure the individual effects of each practice. The coffee pulp compost was made with a passively aerated static pile method (Rynk, 1992). The chemical properties of the coffee pulp compost are shown in Table 1. At the beginning of each STMC, exempting the control, an equivalent of $5 \%$ of $\mathrm{OM}$ as coffee pulp compost was till-incorporated into the top $15 \mathrm{~cm}$ of soil of each plot. Right after till-incorporating the compost, four legume seeds were broadcast over the experimental plots at rates of 42, 14, 13 and $13 \mathrm{~kg} / \mathrm{ha}$ for Canavalia ensiformis, Crotalaria juncea, Mucuna pruriens and Vigna unguiculata, respectively. Three weeks after the legumes were planted, each plot was inoculated with a $2,400 \mathrm{ml} / \mathrm{L}$ aqueous suspension of commercially available mycorrhizae (MycoApply ${ }^{\circledR}$ Soluble Endo), which contained four endomycorrhizal species $(21,450$ propagules $/ \mathrm{kg}$ each). At the end of each STMC, at 60-day intervals, the different legume species were cut at the soil line, chopped, weighed and till-incorporated into the top $15-\mathrm{cm}$ soil depth. On the same date, control plots (receiving none of the above management practices) were tilled as well. Once the different legumes were incorporated into the soil $7.5 \mathrm{~L}$ of compost tea was applied to each plot with a watering can. The compost tea was prepared by mixing $11.5 \mathrm{~kg}$ of mature wood chip compost obtained from a local distributor and $120 \mathrm{~mL}$ of unsulfured molasses in $80 \mathrm{~L}$ of water, which was aerated continuously with an aquarium pump for $24 \mathrm{~h}$. Each new STMC was started seven days after the latest compost tea addition. The STMC corresponding to the CL3, CL2 and CL1 treatments were established at 60-day intervals, so that all treatments were concluded at the same time (Table 2).

TABLE 1. - Chemical properties of coffee pulp compost used in each soil treatment management cycle.

\begin{tabular}{lc}
\hline Parameter & Coffee pulp compost \\
\hline Organic matter $(\%)$ & 60 \\
$\mathrm{pH}$ & 7.13 \\
Total organic $\mathrm{N}(\% \mathrm{~N})$ & 1.61 \\
Available nutrients & \\
$\mathrm{NH}_{4}-\mathrm{N}(\mathrm{mg} / \mathrm{kg})$ & 77 \\
$\mathrm{NO}_{3}(\mathrm{mg} / \mathrm{kg})$ & 14,699 \\
$\mathrm{P}(\mathrm{mg} / \mathrm{kg})$ & 309 \\
$\mathrm{~K}(\mathrm{mg} / \mathrm{kg})$ & 4,781 \\
$\mathrm{Ca}(\mathrm{mg} / \mathrm{kg})$ & 4,020 \\
$\mathrm{Mg}(\mathrm{mg} / \mathrm{kg})$ & 562 \\
$\mathrm{Na}(\mathrm{mg} / \mathrm{kg})$ & $\mathrm{ND}$ \\
\hline
\end{tabular}

$\mathrm{ND}=$ non detectable 
TABLE 2.-Representation of treatment application every 60 days starting with CL3, then CL2 and CL3 at 120 days from eggplant planting. Followed by CL1, CL2 and CL3 60 days before eggplant plantings.

\begin{tabular}{|c|c|c|c|c|}
\hline \multirow[b]{2}{*}{ Days to plant } & \multicolumn{4}{|c|}{ Treatments } \\
\hline & CLO & CL1 & CL2 & CL3 \\
\hline 180 & & & & STMC \\
\hline 120 & & & STMC & STMC \\
\hline 60 & & STMC & STMC & STMC \\
\hline 0 & \multicolumn{4}{|c|}{ Soil sampled and eggplants planted } \\
\hline
\end{tabular}

STMC is soil treatment management cycles. CL0 represents the control where no STMC were applied, CL1 the application of one STMC, CL2 the application of two STMC and CL3 the application of three STMC prior to eggplants planted.

Soil sampling and analysis

Four disturbed soil samples were collected per plot at a depth of 0-15 cm, 12 weeks after treatments were established. The four samples were pooled to form a single sample per plot to test for aggregate stability (AS). At the same time, undisturbed soil cores, one per replication, were gathered to determine water retention (WR) curves. The cores were obtained by driving aluminum cylinders $(7.5 \mathrm{~cm}$ long and 5 $\mathrm{cm}$ in diameter) into the ground and extracting the cores with a shovel.

The soil organic matter was determined by using the Walkley-Black dichromate oxidation technique as described in Nelson and Sommers (1982). Humic acids (HA) were extracted based on their solubility in acids. Briefly, $6 \mathrm{~g}$ of soil was first treated with $0.1 \mathrm{M}$ HCL to extract the fulvic acids. The soil was further treated with $0.1 \mathrm{M} \mathrm{NaOH}$ to obtain the $\mathrm{HA}$. The HA were precipitated by adding sufficient $6 \mathrm{~N} \mathrm{HCl}$ solution to reach a $\mathrm{pH}$ of 1 . After centrifuging and removing the supernatant, the HA precipitates were re-dissolved in a $0.1 \mathrm{~N}$ KOH solution. Samples were then re-precipitated with $6 \mathrm{~N} \mathrm{HCl}$, centrifuged, and re-dissolved with a solution of $0.1 \mathrm{~N} \mathrm{HCl}+0.3 \mathrm{~N}$ hydrofluoric acid. Hydrofluoric acid was included in the last dissolution process to remove silicates. The HA were purified with a cation exchange resin (Dowex 50WX8-100), freeze-dried and quantified by weighing on an analytical balance.

Soil microbial biomass C (MB-C) was quantified by the fumigation-extraction method (Vance et al., 1987) using the equation MB$\mathrm{C}=\mathrm{E}_{\mathrm{C}} / 0.45$, where $\mathrm{E}_{\mathrm{C}}$ is the difference between organic-C extracted by $\mathrm{K}_{2} \mathrm{SO}_{4}$ from fumigated and un-fumigated soil, respectively (Beck et al., 1997). The analyses were performed after wetting the soil to field capacity when laminar water was seen at the top of the samples. The wetted samples were split into two equal portions ( $40 \mathrm{~g}$ fresh weight), one of which was fumigated and incubated with ethanol-free chloroform in glass desiccators at room temperature. The other portion was incubat- 
ed without fumigation for the same period at the same temperature. After $24 \mathrm{~h}$ the chloroform was removed by suction, and $15 \mathrm{~g}$ of soil was extracted with $40 \mathrm{~mL}$ of $0.5 \mathrm{M} \mathrm{K}_{2} \mathrm{SO}_{4}$. For soil microbial C flush determination, dissolved organic $\mathrm{C}$ in the filtered extract was measured with a Rosemount Analytical Dorhmann DC 190 total organic carbon analyzer. For microbial biomass nitrogen (MB-N), total nitrogen was measured after Kjeldahl digestion of the $\mathrm{K}_{2} \mathrm{SO}_{4}$ extract, according to Brookes et al. (1985), using the equation Biomass $\mathrm{N}=\mathrm{F}_{\mathrm{N}} / 0.54$, where $\mathrm{F}_{\mathrm{N}}$ is the $\mathrm{N}$ mineralized from the biomass (Brookes et al., 1985).

Aggregate stability was determined by the wet sieving method (Kemper and Rosenau, 1986). The soil was air-dried, sieved, and the 1.65 to $4.7 \mathrm{~mm}$ sieve fraction was retained. The air-dried aggregate samples were placed on top of a sieve nest of two sieves of 1.65 and $0.68 \mathrm{~mm}$ and agitated in water for $15 \mathrm{~min}$ at a rate of 30 cycles per minute with a wet sieving machine. Fractions of aggregates retained in the sieves were oven-dried at $105^{\circ} \mathrm{C}$ for $24 \mathrm{~h}$ and corrected for sand to obtain the real proportion of soil aggregates (Nyamangara et al., 2001).

Water retention curves were determined on the intact soil cores by placing them on a pressure plate. The hanging water column technique was used to measure WR at hydraulic tension heads of $0,-20,-40,-80$, -160 and $-320 \mathrm{~cm} \mathrm{H}_{2} \mathrm{O}$ (Hall, 1991). A five-bar pressure plate extractor (Dane and Hopmans, 2002) was used to measure WR at $-0.5,-0.6$ and -1.0 bar (approximately $-500,-600$ and $1,000 \mathrm{~cm} \mathrm{H}_{2} \mathrm{O}$, respectively). Pore size distribution was obtained from the WR curve by using the capillary rise equation (Kutilek and Nielsen, 1994). Bulk density was determined by measuring the volume and the oven-dried weight of the undisturbed soil cores used for the WR curve.

Pore-size distributions were inferred from moisture release curves using the capillary rise equation (Kutilek and Nielsen, 1994)

$$
r(\mu \mathrm{m})=\frac{1500}{h(\mathrm{~cm})} \quad \text { Eq. [1] }
$$

where, $\mathrm{r}$ is pore radius in $\mu m$ and $h$ is the matric potential (expressed in hydraulic head units or $\mathrm{cm}_{\mathrm{H}_{2}} \mathrm{O}$ ) required to drain water out of that pore. By Eq. [1], the change in volumetric water content between any two-matric potentials $h_{1}$ and $h_{2}$, determined from the moisture release curves, can be interpreted as the fraction of soil volume occupied by pores with radius between $r_{1}$ and $r_{2}$. By making these determinations for different ranges in $h$ and corresponding pore radii $r$, pore size distributions may be constructed to indicate the relative contribution of pores of different sizes to the total porosity of the soil.

Saturated hydraulic conductivity $\left(K_{s}\right)$ was measured in situ by inserting a sharpened cylinder $10 \mathrm{~cm}$ in diameter and $15 \mathrm{~cm}$ long into the 
soil at a 5 -cm depth. Water was added to the cylinder and allowed to infiltrate the soil, maintaining a constant head of $5 \mathrm{~cm}$ inside the core with a Guelph permeameter. Saturated hydraulic conductivity was determined from the steady state water outflow rate from the permeameter (Reynolds and Elrick, 1985).

Data were analyzed by ANOVA according to a Randomized Complete Block Design, using Fisher's least significant difference $(p \leq 0.05)$ for comparison of means. Correlation analyses were performed using the Pearson Coefficient Analysis. The analyses were performed using Infostat Statistical Software (Di-Rienzo et al., 2011).

\section{RESULTS AND DISCUSSION}

\section{Soil Organic Matter}

The coffee pulp organic matter added at every STMC was equivalent to $5 \%$. This totaled zero OM added for control CL0, $5 \%$ in CL1, $10 \%$ in CL2 and $15 \%$ in CL3. The OM tested amount was $1.01 \%$ in CL0, 2.5\% in CL1, 4.11\% in CL2 and $4.97 \%$ in CL3 (Table 3). This shows that about 50 to 67 percent of the added OM mineralized during the experimental period. This is consistent with other results (Rivero et al., 2004; Bernal et al., 1998), which showed that even though composting produced stable OM, a portion of this OM becomes labile during the first two months after incorporation into the soil. In addition to the compost, fresh residues from the cover crops were incorporated during each STMC, which also contributed to the increase of soil OM. However, since compost and cover crops did not vary independently in our experiments, it is not possible to

TABLE 3.-The effects of soil treatment management cycles (STMC) on the soil organic matter, humic acids content, aggregate stability, bulk density and hydraulic conductivity.

\begin{tabular}{|c|c|c|c|c|c|}
\hline Treatment & $\begin{array}{c}\mathrm{OM}^{1} \\
--(\%)--\end{array}$ & $\begin{array}{c}\mathrm{HA} \\
--(\mathrm{g} / \mathrm{kg})--\end{array}$ & $\begin{array}{c}\text { AS } \\
--(\%)--\end{array}$ & $\underset{-\left(\mathrm{g} / \mathrm{cm}^{3}\right)-}{\mathrm{Bd}}$ & $\begin{array}{c}\mathrm{K}_{\mathrm{s}} \\
--(\mathrm{cm} / \mathrm{h})-\end{array}$ \\
\hline $\mathrm{CLO}^{2}$ & $1.01 \mathrm{~d}^{3}$ & $2.5 \mathrm{~d}$ & $2.65 \mathrm{~d}$ & $1.59 \mathrm{a}$ & $0.463 \mathrm{c}$ \\
\hline CL1 & $2.50 \mathrm{c}$ & $7.1 \mathrm{c}$ & $10.87 \mathrm{c}$ & $1.34 \mathrm{~b}$ & $3.212 \mathrm{~b}$ \\
\hline CL2 & $4.11 \mathrm{~b}$ & $9.7 \mathrm{~b}$ & $16.93 \mathrm{~b}$ & $1.22 \mathrm{c}$ & $6.467 \mathrm{a}$ \\
\hline CL3 & $4.97 \mathrm{a}$ & $15.0 \mathrm{a}$ & $24.01 \mathrm{a}$ & $1.08 \mathrm{~d}$ & $5.576 \mathrm{a}$ \\
\hline
\end{tabular}

\footnotetext{
${ }^{1} \mathrm{OM}=$ organic matter, $\mathrm{HA}=$ humic acids, $\mathrm{AS}=$ aggregate stability, $\mathrm{Bd}=$ bulk density, and $\mathrm{K}$ =hydraulic conductivity.

${ }^{2} \mathrm{CLO}=$ no STMC, CL1=one STMC, CL2=two consecutive STMC, and CL3=three consecutive STMC.

${ }^{3}$ Means within columns followed by the same letter are not significantly different at $p<0.05$ using Fisher's least significant difference (LSD).
} 
infer their relative effects on changes in soil OM with our data. The total oven-dried biomass production of the green manures for STMC ranged from 5,560 to $6,402 \mathrm{~kg} / \mathrm{ha}$ (data not shown). These values are considerably larger than those reported for biomass production of individual legume species. In 20 trials at five localities in Puerto Rico, Carlo (2009) reported biomass production ranges of 822 to $4,175 \mathrm{~kg}$ / ha for Canavalia ensiformis, 821 to $2,509 \mathrm{~kg} / \mathrm{ha}$ for Crotalaria juncea, 482 to $2,721 \mathrm{~kg} / \mathrm{ha}$ for Mucuna pruriens and 340 to $1,461 \mathrm{~kg} / \mathrm{ha}$ for Vigna unguiculata. These results indicate that mixed plantings of these tropical legume cover crops can produce more biomass and possibly more fixed $\mathrm{N}$ than individual plantings of the same crops. In the present study, the HA fraction of OM in amended soils ranged from $23.6 \%$ to $30.1 \%$ without any specific trend. All organic treatments reported an increase of HA (CL3 > CL2 > CL1 > CL0) over non-amended soil (Table 3). The HA content ranged from $2.5 \mathrm{~g} / \mathrm{kg}$ in the CL0 to $15 \mathrm{~g} / \mathrm{kg}$ in CL3.

\section{Microbial biomass}

After the incorporation of three consecutive STMC (CL3), microbial biomass C (MB-C) increased 3.8 times (366.6 $\mu \mathrm{g} \mathrm{C} / \mathrm{g}$ dry soil) relative to the non-amended soil treatment CL0 (96.6 $\mathrm{gg}$ C/g dry soil) (Table 4). Treatments CL1 and CL2, though higher than CL0, were not statistically different because of the high variability of the results. The CL2 (80.3 $\mu \mathrm{g} \mathrm{C/g}$ dry soil) and CL3 (117.1 $\mu \mathrm{g} \mathrm{C/g}$ dry soil) treatments produced significantly higher levels of microbial biomass N (MB-N) than the non-amended soil (10.2 $\mu \mathrm{g} \mathrm{C/g}$ dry soil) (CL3 > CL2 > CL1 = CL0). In treatments CL2 and CL3, MB-N increased 7.9 and 11.5 times, respectively, over the non-amended soils. The increase of microbial activity after the application of organic residues has been attributed to the input of easily degradable materials (Blagodatsky et al., 2000; Carpenter et al., 2000; Franchini et al., 2007). Other authors have noted

TABLE 4.-Microbial biomass carbon and nitrogen after the implementation of the soil treatment management cycles of compost application, planting, growth and incorporation of four green manure species, mycorrhizae and compost tea.

\begin{tabular}{lcc}
\hline Identification & $\begin{array}{c}\text { Microbial Biomass-C } \\
(\mu g \text { C/g dry soil) }\end{array}$ & $\begin{array}{c}\text { Microbial Biomass-N } \\
(\mu \mathrm{g} \mathrm{N} / \mathrm{g} \text { dry soil })\end{array}$ \\
\hline CL0 & $96.62 \mathrm{~b}$ & $10.2 \mathrm{c}$ \\
CL1 & $207.4 \mathrm{ab}$ & $40.6 \mathrm{c}$ \\
CL2 & $212.1 \mathrm{ab}$ & $80.3 \mathrm{~b}$ \\
CL3 & $366.6 \mathrm{a}$ & $117.1 \mathrm{a}$ \\
\hline
\end{tabular}

Means within columns followed by the same letter are not significantly different at $p<0.05$ using Fisher's least significant difference (LSD). 
a direct relation between the enhanced soil physical properties like structure and porosity and an increase in biological activity after organic amendments are added (Marinari et al., 2000; Tejada et al., 2006; Annabi et al., 2011). The microbial population of the compost could partially explain the increase in soil microbial biomass (Beffa et al., 1995). However, the effect of legume and non-legume cover crops in enhancing microbial activity has also been reported (Schulz, 2003; Tilak, 2004; Tejada et al., 2008a).

Aggregate stability

The STMC increased AS percentage at every level of the consecutive treatments. The increase was $2.65 \%, 10.87 \%, 16.93 \%$ and $24.01 \%$ for CL0, CL1, CL2 and CL3, respectively (Table 3). Correlations were observed between AS and organic amendment components such as $\mathrm{OM}$ (Figure 1), humic acid (Figure 2), microbial biomass $\mathrm{C}$ and microbial biomass $\mathrm{N}$ (Figure 3). Other published results concur with this data as to the importance of $\mathrm{OM}$ and its various components as cementing agents of soil particles (Nyamangara et al., 2001; Ferreras et al., 2006; Abiven et al., 2009). Mature compost has been related to long-term increases in AS principally through the effect of humic substances (Annabi et al., 2011). On the other hand, green manures have been related to short-term effects on AS associated with the production of microbial exudates (Golchin et al., 1994; Liu et al., 2005; Abiven et al., 2009). From our data, however, it is difficult to separate the effects of compost on AS from those of legume cover crops because the two parameters

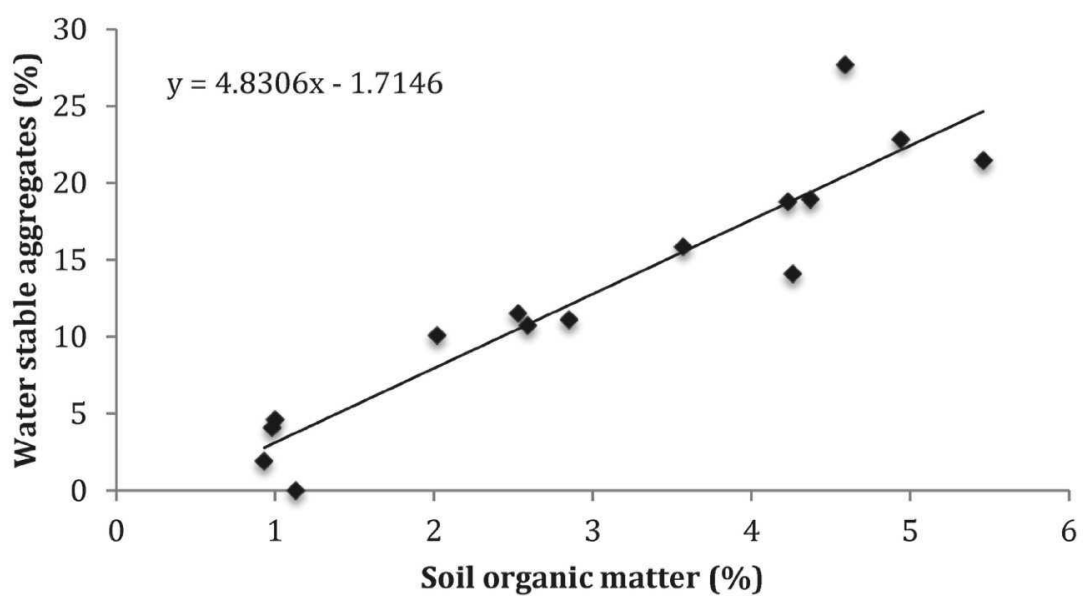

FIGURE 1. Water stable aggregates in relation to soil organic matter content $(r=0.94)$. 


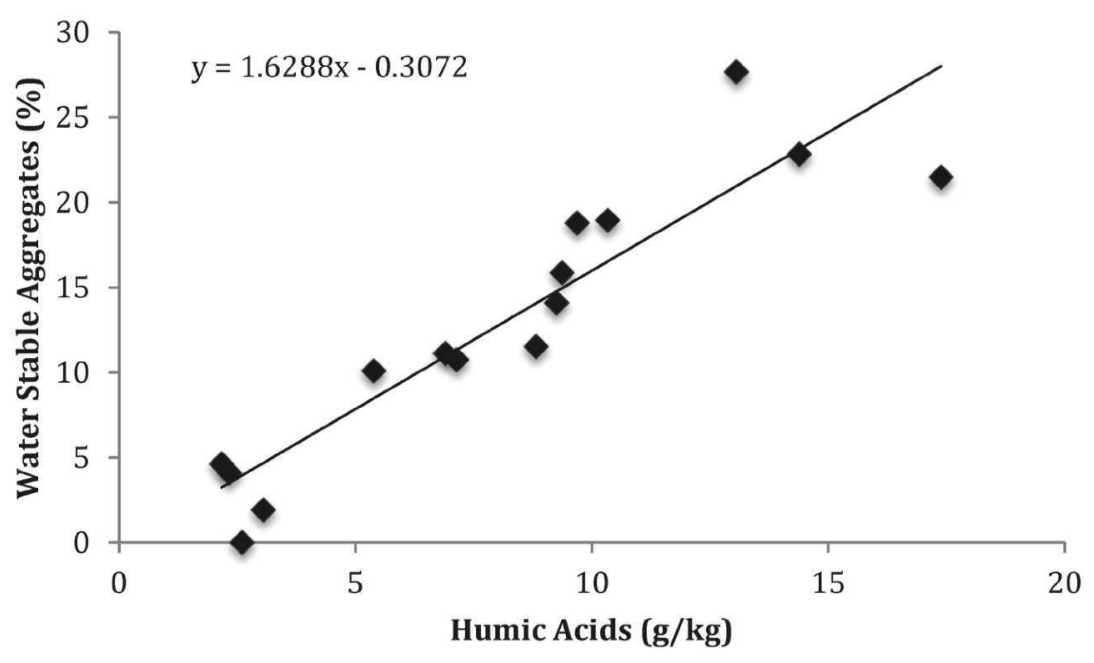

FIGURE 2. Water stable aggregates in relation to humic acid content $(\mathbf{r}=0.92)$.

were not varied independently. Regressions between AS and OM, HA, MB-C and MB-N are shown in Figures 1 to 3 . The regressions in all cases were significant. However, it is difficult to establish which of these parameters had the greatest effect on AS, because OM, HA, MB-C and MB-N are all strongly correlated to each other (see correlation matrix in Table 5). Also, the experimental design did not allow discriminating between individual effects of compost and cover crops on AS.

\section{Bulk density}

Table 3 shows the effects of the STMC on soil Bd. As the STMC increased the soil $\mathrm{Bd}$ was reduced from $1.59 \mathrm{~g} / \mathrm{cm}^{3}$ (CL0) to $1.34 \mathrm{~g} / \mathrm{cm}^{3}$ (CL1) then to $1.22 \mathrm{~g} / \mathrm{cm}^{3}$ (CL2) and finally to $1.08 \mathrm{~g} / \mathrm{cm}^{3}$ in CL3. These results concurred with Khaleel et al. (1981), who reviewed experiments of organic residue application and found a constant positive relationship between reduction of $\mathrm{Bd}$ and application of organic residues in 21 soil types and eight different organic residues evidencing the generally positive effect of the organic amendment in $\mathrm{Bd}$. The reduction in $\mathrm{Bd}$ after the addition of an organic amendment is attributed to the dilution of denser soil particles and to an increase in porosity resulting from the enhanced structural stability (Tejada et al., 2009). As seen here, all treatments reflected an increase in soil OM content (Table 3 ), increasing the proportion of less-dense material in the soil matrix. The reduction of $\mathrm{Bd}$ cannot be attributed solely to the decrease in the proportion of denser particles. Bulk density has previously been re- 


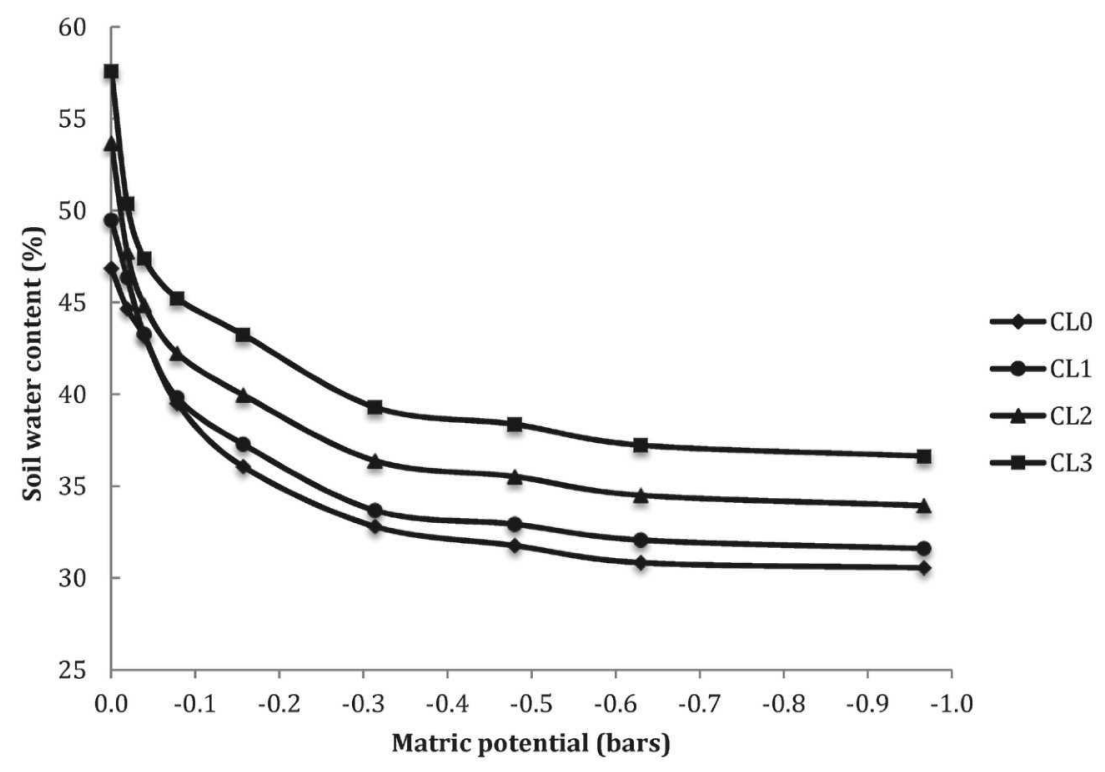

FIGURE 3. Water retention curves of soils after the implementation of different numbers of soil treatment management cycles (STMC) of compost application, planting and incorporation of four green manure species, mycorrhizae and compost tea. CLO 0 no STMC, CL1=one STMC, CL2=two consecutive STMC, and CL3=three consecutive STMC.

ported to decrease in response to an increase in AS and porosity due to the addition of composted organic residues (Marinari et al., 2000) and the incorporation of green manures (Fischler et al., 1999). In our experiments AS gradually increased with increasing STMC, which was accompanied by a decrease in $\mathrm{Bd}$. Our results are in accordance with those of other studies that have reported reductions in Bd by incorporating green manures and compost (Tejada and Gonzalez 2006; Tejada et al., 2006; Tejada et al., 2009).

\section{Water retention curves and pore size distributions}

Figure 3 shows the WR curves for the 0 to -1 bar matric potential range, corresponding to the different treatments. As the number of STMC of combined practices increased from CL1 to CL3, there was an increase in WR at all tensions as shown by an approximately parallel upward displacement of curves. The CLO WR was similar to that of CL1 at any tension. An analysis of variance at each tension applied was carried out, and results showed that treatments CL2 and CL3 increased WR capacity for all tensions studied. Treatment CL3 was more efficient than CL2, increasing WR capacity at all tensions except for 
TABLE 5.-Correlation matrix ( $r$ ) of soil parameters affecting aggregate stability.

\begin{tabular}{lccccc}
\hline & AS & OM & HA & MB-C & MB-N \\
\hline AS & 1.00 & & & & \\
OM & 0.94 & 1.00 & & & \\
HA & 0.92 & 0.96 & 1.00 & & \\
MB-C & 0.59 & 0.64 & 0.68 & 1.00 & \\
MB-N & 0.89 & 0.92 & 0.89 & 0.48 & 1.00 \\
\hline
\end{tabular}

$\mathrm{AS}=$ aggregate stability; $\mathrm{OM}=$ organic matter; $\mathrm{HA}=$ humic acid; $\mathrm{MB}-\mathrm{C}=$ soil microbial biomass carbon; MB-N= soil microbial biomass nitrogen.

-0.0196 and -0.0392 bar, which were not significantly different. Treatments CL2 and CL3 increased WR at saturated conditions about 15.5\% and $23.0 \%$, respectively. This finding represents the greater potential of rainwater conservation since the water storage of this soil increased with the application of two (CL2) and three (CL3) consecutive STMC. The observed increase in OM content (Table 3) explains the enhancement in WR capacity. The contribution of OM on WR itself explains water dynamics retained at high suctions (Rawls et al., 2003), but the structure forming effect of OM is more likely to explain the WR dynamics between 0 to -1 bar (Snyder et al., 1993; Sharma and Uehara, 1968).

An increase in AS is expected to be accompanied by an enhancement in WR since it has been demonstrated that inter-aggregate pores play a major role in WR at suctions between 0 to -0.3 bar (Sharma and Uehara, 1968). Soil pore size distributions produced by the experimental treatments CLO - CL3 are shown in Table 6, indicating fractions of soil pore space corresponding to pores in the radius ranges 2 to 5 , 5 to 9,9 to 19,19 to 38 and $>38 \mu \mathrm{m}$. The greatest treatment effect was on porosity associated with pores $>38 \mu \mathrm{m}$ (Table 6). Treatments CL1, CL2, and CL3 caused increases in $>38 \mu \mathrm{m}$ porosity which were respectively $1.6,2.1$, and 2.2 times the value for the CL0 treatment. Pores of radius $>38 \mu \mathrm{m}$ are commonly considered macropores associated with inter-aggregate space produced by aggregation (Hillel, 2004). The greater changes in pore size distribution were reported in this pore size category, evidencing the role of inter-aggregate porosity in WR in 0 to -1 bar suctions. Our results are in accordance with those authors who have reported a direct relationship between a reduced Bd (Madankumar, 1985) as the result of organic amendments, and the increase of WR capacity (Pérez-de-los-Reyes et al., 2011). An opposite trend was observed for porosities corresponding to pore-size ranges smaller than $38 \mu \mathrm{m}$ (Table 6). In most of these cases, porosities decreased with an increasing number of STMC. This indicates that within the domain of pore radii studied $(>2 \mu \mathrm{m}$ ), the increase in porosity associated with 
TABLE 6.-Pore size distribution as affected by soil treatment management cycles (STMC) of compost application, planting, growth and incorporation of four green manure species, mycorrhizae and compost tea.

\begin{tabular}{lccccc}
\hline & \multicolumn{5}{c}{ Pore size (radius) } \\
\cline { 2 - 6 } Identification & $>38 \mu \mathrm{m}$ & 19 to $38 \mu \mathrm{m}$ & 9 to $19 \mu \mathrm{m}$ & 5 to $9 \mu \mathrm{m}$ & 2 to $5 \mu \mathrm{m}$ \\
\hline & --- percent of soil volume corresponding to pores in the given size range --- \\
CL0 & $7.9 \mathrm{~b}$ & $7.7 \mathrm{a}$ & $7.3 \mathrm{a}$ & $6.9 \mathrm{a}$ & $4.2 \mathrm{a}$ \\
CL1 & $12.2 \mathrm{ab}$ & $7.0 \mathrm{ab}$ & $5.2 \mathrm{~b}$ & $7.3 \mathrm{a}$ & $3.3 \mathrm{ab}$ \\
CL2 & $16.3 \mathrm{a}$ & $4.9 \mathrm{bc}$ & $4.2 \mathrm{bc}$ & $6.7 \mathrm{a}$ & $3.5 \mathrm{ab}$ \\
CL3 & $17.5 \mathrm{a}$ & $3.8 \mathrm{c}$ & $3.5 \mathrm{c}$ & $6.9 \mathrm{a}$ & $3.6 \mathrm{~b}$ \\
\hline
\end{tabular}

Means within columns followed by the same letter are not significantly different at $p<0.10$ using Fisher's least significant difference (LSD). CL0=no STMC, CL1=one STMC, CL2=two consecutive STMC, and CL3 =three consecutive STMC.

pores $>38 \mu \mathrm{m}$ occurred at the expense of a decrease in porosity associated with the smaller pores.

\section{Hydraulic conductivity}

All treatments showed significantly higher values of $\mathrm{K}_{\mathrm{s}}$ compared with that of the non-amended soil (Table 3). The CL1 treatment $\left(\mathrm{K}_{\mathrm{s}}=3.212 \mathrm{~cm} / \mathrm{h}\right)$ was seven times greater than the $\mathrm{CLO}\left(\mathrm{K}_{\mathrm{s}}=0.463 \mathrm{~cm} / \mathrm{h}\right)$ while CL2 $(6.467 \mathrm{~cm} / \mathrm{h})$ and CL3 $(5.576 \mathrm{~cm} / \mathrm{h})$ reported a 14 - and 12 -fold increase, respectively. However, no statistical differences were encountered between the CL2 and CL3 treatments. These results are in accordance with those of various authors (Khaleel et al., 1981; Aggelides and Londra, 2000) who have reported increases in $\mathrm{K}_{\mathrm{s}}$ as the result of increased porosity after OM additions. As supported by the enhancement in AS (Table 3) and the increase in the proportion of macropores (Table 6), the enhancement of water conductivity is attributed to greater production and connectivity of macro-pores due to more stable aggregates (Zhang et al., 2011). As pointed out, the incorporation of green manures promotes the development of microbial-associated enhancement of AS favoring the development of inter-aggregate pores. Fischler et al. (1999) reported a $51 \%$ increase of water infiltration in a tropical soil associated with an increase in the number of macropores after the incorporation of Crotalaria sp. cover crop residues. In our experiment, the presence of undecayed legume residues mixed within the soil was still obvious eight weeks after the incorporation of the green manures, which may have contributed to the stabilization of aggregates. The effect of undecayed cover crop roots and stalks and the biological action protecting macropores has already been pointed out (Strudley et al., 2008). These results are transcendent for this soil since efforts have been made in this soil series to increase $K_{s}$ in order to reduce the in- 
cidence of soil-borne diseases during the rainy season (Torres, 2009). For optimum crop development a balance should be reached between hydraulic soil properties, where $\mathrm{K}_{\mathrm{s}}$ values should be high enough to favor the drainage of excess water. However, WR should be high enough to provide the plant with a source of water in non-saturated conditions (Keller et al., 2012). The combined sustainable practices assessed in this study demonstrated the capacity to enhance soil hydraulic dynamics where $\mathrm{K}_{\mathrm{s}}$ was enhanced and at the same time, WR capacity increased as a result of implementing STMC compared with that of CLO.

\section{CONCLUSION}

The STMC of combined practices promoted a general enhancement in soil properties expressed by a reduction in $\mathrm{Bd}$ and an increase in AS, OM content, microbial activity and $\mathrm{K}_{\mathrm{s}}$. Two STMC (CL2) were usually sufficient and three STMC (CL3) changed all the physical and biological parameters assessed in this study $\left(\mathrm{OM}, \mathrm{AS}, \mathrm{K}_{\mathrm{s}}\right.$, WR capacity, $\mathrm{Bd}$, MB-C and MB-N). In this manner, the establishment of two STMC (CL2) was enough to attain the most desirable improvement for agricultural soil development. Even one STMC significantly increased $\mathrm{OM}$ content, $\mathrm{K}_{\mathrm{s}}$, and decreased $\mathrm{Bd}$. The incorporation of STMC of combined sustainable practices presented in this study may be considered a soil improvement tool since the adoption of these practices had a cumulative positive effect on soil physical parameters. Since all organic amendments were applied in a confounding manner to mimic the overall effect of a sustainable agricultural system (i.e., they were not varied independently of each other), it is difficult to establish which specific amendment had the greatest effect on soil physical properties. Similarly, it is difficult to establish which of the OM components (total OM, HA, MB-C or MB-N) had the strongest influence on AS and associated physical properties. The fraction which best correlated with AS was $\mathrm{HA}$, but HA also co-varied strongly with other indicators such as total $\mathrm{OM}$ and microbial $\mathrm{C}$ and $\mathrm{N}$, which introduces confounding elements. Organic matter was the key element that triggered the betterment effect of our treatments, but the HA fraction had the strongest influence on AS. The production of stable aggregates positively influenced the other physical parameters assessed in this study by modifying pore size distribution. These results point out the importance of OM management in agroecosystems. However, regardless of the specific mechanisms involved, this study clearly shows that organic amendments can have very strong positive effects on soil physical properties, which influence agronomical factors that can enhance crop yields. Effects on yields are documented in a companion paper (Pagán-Roig et al., 2016). 


\section{LITERATURE CITED}

Abiven, S., S. Menasseri and C. Chenu, 2009. The effects of organic inputs over time on soil aggregate stability-a literature analysis. Soil Biol. Biochem. 41: 1-12.

Aggelides, S. M. and P. A. Londra, 2000. Effects of compost produced from town wastes and sewage sludge on the physical properties of a loamy and a clay soil. Bioresource Technology 71: 253-259.

Altieri, M. A. and C. Nicholls, 2003. Soil fertility management and insect pests: Harmonizing soil and plant health in agroecosystems. Soil Tillage Research 72: 203-211.

Annabi, M., Y. Le Bissonnaisc, M. Le Villio-Poitrenaudb and S. Houot, 2011. Improvement of soil aggregate stability by repeated applications of organic amendments to a cultivated silty loam soil. Agriculture, Ecosystems and Environment 144: 382-389.

Beck, T., R. G. Joergensen, E. Kandeler, F. Makeschin, E. Nuss, H. R. Oberholzer and S. Scheu, 1997. An inter-laboratory comparison of ten different ways of measuring soil microbial biomass C. Soil Biol. Biochem. 29: 1023-1032.

Beffa, T., M. Blanc, L. Marilley, J. Lott Fisher, P. F. Lyon and M. Aragno, 1995. Taxonomic and metabolic microbial diversity during composting. In: M. De Bertoldi, P. Sequi, B. Lemmes and T. Papi (eds). The Science of Composting, pp 149-161.

Bernal, M.P., M. A. Sánchez, C. Paredes and A. Roig, 1998. Carbon mineralization from organic wastes at different composting stages during their incubation with soil. Agriculture, Ecosystems and Environment 69: 175-189.

Blagodatsky, S., O. Heinemeyer and J. Richter, 2000. Estimating the active and total soil microbial biomass by kinetic respiration analysis. Biol. Fertil Soils 32: 73-81.

Brookes, P. C., J. F. Kragt, D. S. Powlson and D. S. Jenkinson, 1985. Chloroform fumigation and the release of soil nitrogen: effects of fumigation time and temperature. Soil Biology and Biochemistry 17: 831-835.

Bumb, B. L. and C. A. Baanante, 1996. The role of fertilizers in sustaining food security and protecting the environment to 2020. Food, Agriculture, and the Environment Discussion Paper No. 17, International Food Policy Research Institute, Washington, DC. 54 pp.

Cardoso, I. M. and T. W. Kuyper, 2006. Mycorrhizas and tropical soil fertility. Agriculture, Ecosystems and Environment 116: 72-84.

Carlo, S. I., 2009. Promoting the use of tropical legumes as cover crops in Puerto Rico. M.S. Thesis. University of Puerto Rico-Mayagüez, Puerto Rico.

Carpenter, L., A. C. Kennedy and J. P. Reganold, 2000. Organic and biodynamic management: Effects on soil biology. Soil Sci. Soc. Am. J. 64: 1651-1659.

Carter, M. R., E. G. Gregorich, D. A. Angers, M. H. Beeare, G. P. Sparling, D. A. Wardle and R. P. Voroney, 1999. Interpretation of microbial biomass measurements for soil quality assessment in humid regions. Can. J. Soil Sci. 79: 507-520.

Dane, J. H. and J. W. Hopmans, 2002. 3.3 Water Retention and Storage. 3.3.2.4 Pressure Plate Extractor. p. 688-690. In J. H. Dane and G. C. Topp (eds.). Methods of Soil Analysis, Part 4 - Physical Methods. Soil Sci. Soc. Am. Book Series No. 5. Madison, WI.

Di-Rienzo, J. A., F. Casanoves, M. G. Balzarini, L. González, M. Tablada and C. W. Robledo, 2011. InfoStat versión 2011. Grupo InfoStat, FCA, Universidad Nacional de Córdoba, Argentina. URL http://www.infostat.com.ar.

Drinkwater, L. E., D. K. Letourneau, F. Workneh, A. H. C. Van Bruggen and C. Shennan, 1995. Fundamental differences between conventional and organic tomato agroecosystems in California. Ecological Applications 5: 1098-112.

FAO, 1999. Integrated soil management for sustainable agriculture and food security in Southern and East Africa, Proceedings of the Harare Expert Consultation, by Nabhan, H., M. A. Mashali, A. R. Mermut (eds). AGL/MISC/23/99, Rome.

Ferreras, L., E. Gómez, S. Toresani, I. Firpo and R. Rotondo, 2006. Effect of organic amendments on some physical, chemical and biological properties in a horticultural soil. Bioresource Technology 97: 635-640.

Fischler, M., C. S. Wortmann and B. Feil, 1999. Crotalaria (C. ochroleuca G. Don.) as a green manure in maize-bean cropping systems in Uganda. Field Crops Research 61: 97-107. 
Franchini, J. C., C. C. Crispino, R. A. Souza, E. Torres and M. Hungria, 2007. Microbiological parameters as indicators of soil quality under various soil management and crop rotation systems in southern Brazil. Soil \& Tillage Research 92: 18-29.

Golchin, A., J. M. Oades, J. O. Skjemstad and P. Clarke, 1994. Soil structure and carbon cycling. Australian Journal of Soil Research 32: 1043-1068.

Gunapala, N. and K. M. Scow, 1998. Dynamics of soil microbial biomass and activity in conventional and organic farming systems. Soil Biol. Biochem. 30: 805-816.

Hall, D.G.M., 1991. Relationship between moisture retention characteristics and other soil properties for Zimbabwe soils. Zimbabwe J. Agric. Res. 29: 53-63.

Henao, J. and C. Baanante, 2006. Agricultural production and soil nutrient mining in Africa: Implication for resource conservation and policy development. IFDC Tech. Bull. International Fertilizer Development Center. Muscle Shoals, AL.

Hillel, D., 2004. Introduction to Environmental Soil Physics. Elsevier Academic Press, Amsterdam.

Keller, T., J. A. Sutter, K. Nissen and T. Rydberg, 2012. Using field measurement of saturated soil hydraulic conductivity to detect low-yielding zones in three Swedish fields. Soil \& Tillage Research 124: 68-77.

Kemper, W. D. and R. C. Rosenau, 1986. Aggregate stability and size distribution. In: Methods of soil analysis. Part 1: Physical and mineralogical methods. A. Klute (ed) (Monogr. 9, 2nd edn). ASA, Madison, WI.

Khaleel, R., K. Reddy and M. R. Overcash, 1981. Changes in soil physical properties due to organic waste applications: A review. Journal Environmental Quality 10: 133-141.

Kutilek, M. and D. R. Nielsen, 1994. Soil Hydrology. Catena-Verlag. p. 53.

Lal, R., 2000. Physical management of soils of the tropics: Priorities for the 21 st century. Soil Science 165: 191-207.

Lal, R., 2004. Soil carbon sequestration impacts on global climate change and food security. Science 304: 1623-1627.

Lal, R., 2007. Anthropogenic influences on world soils and implications to global food security. Advances in Agronomy 9: 69-93.

Liu, A., B. L. Ma and A. A. Bomke, 2005. Effects of cover crops on soil aggregate stability, total organic carbon, and polysaccharides. Soil Sci. Soc. Am. J. 69: 2041-2048.

Madankumar, N., 1985. Prediction of soil moisture characteristics from mechanical analysis and bulk density data. Agricultural Water Management 10: 305-312.

Marinari, S., G. Masciandaro, B. Ceccanti and S. Grego, 2000. Influence of organic and mineral fertilisers on soil biological and physical properties. Biores. Technol. 72: 9-17.

Nelson, D. W. and L. E. Sommers, 1982. Total carbon, organic carbon, and organic matter. pp 539-580, In: Page, A.L. et al., (eds.) Methods of soil analysis. Part 2: Chemical and microbial methods. 2nd ed. Agron. Monogr. 9. ASA and SSSA, Madison, WI.

Nyamangara, J., J. Gotosab and S. E. Mpofuc, 2001. Cattle manure effects on structural stability and water retention capacity of a granitic sandy soil in Zimbabwe. Soil \& Tillage Research 62: 157-162.

Oberson, A., E. K. Bunemann, D. K. Friesen, I. M. Rao, P. C. Smithson, B. L. Turner and E. Frossard, 2006. Improving phosphorus fertility in tropical soils through biological interventions, In: N. Uphoff, A. S. Ball, E. Fernandes, H. Herren, O. Husson, M. Laing, C. Palm, J. Pretty, P. Sanchez, N. Sanginga and J. Thies (eds). Biological approaches to sustainable soil systems. CRA, Boca Raton, FL, pp 531-546.

Pagán-Roig, I. C., J. A. Chong, J. A. Dumas and C. Estévez de Jensen, 2016. Combined organic amendment effects on eggplant yield, soil fertility characteristics and humic acid quality. J. Agric. Univ. P.R. 100(2): 101-122.

Pérez-de-los-Reyes, C., J. A. Amorós, F. J. García, S. Bravo, C. Sánchez, D. Chocano and R. Jiménez-Ballesta, 2011. Changes in water retention properties due to the application of sugar foam in red soils. Agricultural Water Management 98: 1834-1839.

Pimentel, D., C. Harvey, P. Resosudarmo, K. Sinclair, D. Kurz, M. McNair, S. Crist, L. Shpritz, L. Fitton, R. Saffouri and R. Blair, 1995. Environmental and economic costs of soil erosion and conservation benefits. Science 267: 1117-1123. 
Pinstrup-Andersen, P. and R. Pandya-Lorch, 1998. Food security and sustainable use of natural resources: A 2020 vision. Ecological Economics 26: 1-10.

Rawls, W. J., Y. A. Pachepsky, J. C. Ritchie, T. M. Sobecki and H. Bloodworth, 2003. Effect of soil carbon on soil water retention. Geoderma 116:61-76.

Reeves, D. W., 1997. The role of soil organic matter in maintaining soil quality in continuous cropping systems. Soil \& Tillage Research 43: 131-167.

Reynolds, W. D. and D. E. Elrick, 1985. In situ measurement of field saturated hydraulic conductivity, sorptivity, and the alpha-parameter using the Guelph permeameter. Soil Sci. 140: 292-302.

Rivero, C., T. Chirenje, L. Q. Ma and G. Martínez, 2004. Influence of compost on soil organic matter quality under tropical conditions. Geoderma 123: 355-361.

Rynk, R. (Ed.), 1992. On-Farm Composting Handbook. Northeast Regional Agricultural Engineering Service. NRAES-54. P-29.

Schulz, M. L., 2003. The effects of cover crops in no-till systems on microbial activity. Cantaurus 11: 31-35.

Sharma, M. L. and G. Uehara, 1968. Influence of soil structure in low humic latosols: I. Water retention. Soil Sci. Soc. Am. Proc. 32: 765-770.

Six, J., H. Bossuyt, S. Degryze and K. Denef, 2004. A history of research on the link between (micro) aggregates, soil biota, and soil organic matter dynamics. Soil \& Tillage Research 79: 7-31.

Snyder, V. A., R. Pietri, M. Miró and H. M. Lugo, 1993. Structural stability, pore size distribution and surface charge properties of clay soils with varying mineralogy and organic matter content. J. Agric. Univ. P.R. 77: 11-31.

Strudley, M. W., T. R. Green and J. C. Ascough II, 2008. Tillage effects on soil hydraulic properties in space and time: state of the science. Soil \& Tillage Research 99: 4-48.

Tejada, M., C. García, J. L. González and M. T. Hernández, 2006. Use of organic amendment as a strategy for saline soil remediation: Influence on the physical, chemical and biological properties of soil. Soil Biology \& Biochemistry 38: 1413-1421.

Tejada, M. and J. L. González, 2006. Crushed cotton gin compost on soil biological properties and rice yield. Europ. J. Agronomy 25: 22-29.

Tejada, M., J. L. González, A. M. García-Martínez and J. Parrado, 2008a. Effects of different green manures on soil biological properties and maize yield. Bioresource Technology 99: 1758-1767.

Tejada, M., J. L. González, A. M. García-Martínez and J. Parrado, 2008b. Application of a green manure and green manure composted with beet vinasse on soil restoration: Effects on soil properties. Bioresource Technology 99: 4949-4957.

Tejada, M., M. T. Hernández and C. García, 2009. Soil Restoration using composted plant residues: effect on soil properties. Soil \& Tillage Research 102: 109-117.

Tejada, M., J. L. Moreno, M. T. Hernández and C. García, 2007. Application of two beet vinasse forms in soil restoration: Effects on soil properties in an arid environment in southern Spain. Agriculture, Ecosystems and Environment 119: 289-298.

Tilak, K. V. B. R., 2004. Response of Sesbania green manuring and mungbean residue incorporation on microbial activities for sustainability of a rice-wheat cropping system. Journal of Agriculture and Rural Development in the Tropics and Subtropics 105: 189-196.

Torres, B. E., 2009. Relación entre propiedades del suelo y el efecto de coberturas vegetales en el aguacate (Persea americana Mill). M.S. Thesis. University of Puerto Rico-Mayagüez, Puerto Rico.

Vance, E. D., P. C. Brookes and D. S. Jenkinson, 1987. An extraction method for measuring microbial mass carbon. Soil Biol. Biochem. 19: 703-707.

Zhang, G., K.Y. Chan, G. D. Li and G. Huang, 2011. The effects of stubble retention and tillage practices on surface soil structure and hydraulic conductivity of a loess soil. Acta Ecológica Sinica 31: 298-302.

Zhao, Y, P. Wang, J. Li, Y. Chen, X. Ying and S. Liu, 2009. The effects of two organic manures on soil properties and crop yields on a temperate calcareous soil under a wheat-maize cropping system. European Journal of Agronomy 31: 26-42. 